\title{
Pythium phragmitis sp. nov., a new species close to $P$. arrhenomanes as a pathogen of common reed (Phragmites australis)
}

\author{
Jan NECHWATAL, Anna WIELGOSS and Kurt MENDGEN \\ Universität Konstanz, Phytopathologie, D-78457 Konstanz, Germany. \\ E-mail:jan.nechwatal@uni-konstanz.de \\ Received 21 April 2005; accepted 5 August 2005.
}

\begin{abstract}
During a study on the occurrence and pathogenicity of oomycetes in the reed-belt (Phragmites australis) of Lake Constance (Germany), a new Pythium resembling the important cereal pathogen species complex $P$. arrhenomanes $/ P$. graminicola was consistently isolated from necrotic mature reed leaves and reed rhizosphere samples. The new species proved to be significantly more aggressive towards reed leaves and seedlings in vitro than related species. It is characterised by filamentous, inflated sporangia and plerotic oospores with usually more than one antheridium. ITS and cox II sequence data indicate this new species shares a common ancestor with P. arrhenomanes, but the sequence differences are clearly consistent with a divergence of the two taxa and with $P$. phragmitis being a distinct species. ITS 1 and 2 of 15 isolates of the taxon consistently differed from P. arrhenomanes by 13 positions. Sequence analyses of the cox II gene confirmed the new species' phylogenetic position. This paper gives a formal description of the taxon as $P$. phragmitis sp. nov., providing information on morphology, ecology and pathogenicity in comparison to related species. As indicated by the close association to Phragmites australis, the high aggressiveness towards reed leaves and seedlings, and the abundance in the investigated stands, Pythium phragmitis might act as a reed pathogen of considerable importance, in particular under flooding situations.
\end{abstract}

\section{INTRODUCTION}

Common reed (Phragmites australis, Poaceae), a large perennial wetland grass, is a major component of littoral plant communities of freshwater lakes in the Northern Hemisphere, forming large natural monocultures with important ecological functions (Haslam 1972). Within the last 50 years, dieback of reed stands has been a periodically recurring threat to littoral ecosystems of many European freshwater lakes (Brix 1999). Lake Constance, one of Europe's largest inland water bodies, is also affected by the decline, and its reed belt dynamics have been investigated in great detail (e.g. Ostendorp, Dienst \& Schmieder 2003, Dienst, Schmieder \& Ostendorp 2004). Adverse effects of lake water eutrophication, organic acid toxicity, wave action, water level regulation, insect attack, algal mats, and low genetic diversity have repeatedly been suggested as possible reasons for the decline (Ostendorp 1989, Brix 1999). A negative impact of extreme floods on reed stand health due to impaired oxygen supply of rhizomes and submerged shoots has already been observed in the 19th century (Honsell 1879). It currently seems to be accepted as a major factor in Lake Constance reed dieback, and is under discussion in the context of global warming, and of subsequent environmental changes on a more local scale (Ostendorp et al. 2003, Dienst et al. 2004).

The fungal community associated with reed has quite extensively been investigated, with a main focus on endophytic and saprobic fungi (e.g. Wirsel et al. 2001, Wong \& Hyde 2001). Some fungal endophytes were found to have beneficial effects on reed performance in vitro (Ernst, Mendgen \& Wirsel 2003). However, a contributing role of fungal pathogens in the dieback of reed has only rarely been addressed (e.g. Bán, Fischl \& Virányi 1996). Similarly, while free water of freshwater lakes was shown to harbour large numbers of propagules of several oomycete species (e.g. Hallett \& Dick 1981), information on their occurrence and pathogenicity in reed stands is scarce. Plant diseases caused by oomycetes are often encountered under water-logged or wet soil conditions as found in littoral ecosystems such as reed belts, as high soil water contents will facilitate zoospore dispersal and mediate disease spread. In particular, species of the genus Pythium are economically significant soilborne pathogens with worldwide distribution, causing root and fruit rot, pre- or post-emergence seedling damping-off, or fine root disorders of numerous different host plants (van der Plaats-Niterink 1981). Cereals and grasses, such as wheat, maize, sugar-cane or Lolium spp. are 
among the major hosts of this genus, and a particular group of Pythium spp., the $P$. graminicola/P . arrhenomanes species complex (Hendrix \& Papa 1974), is specifically associated with diseases of such gramineous host plants (Hendrix \& Campbell 1973). Up to now, Pythium spp. are not known to be substantially involved in diseases of natural, unmanaged plant communities, and rather cause yield losses in agricultural systems. However, much knowledge has accumulated within the past decade on the possible involvement of Pythium spp. in plant diseases or seedling losses in natural ecosystems, and their potential influence on plant community composition (e.g. Mills \& Bever 1998, Packer \& Clay 2000, Nechwatal \& Oßwald 2001). In this study, extensive investigations on the occurrence of Pythium spp. in P. australis stands of Lake Constance, Germany were carried out in order to assess their potential influence on reed vitality and performance, and their role in reed dieback phenomena. During the course of the survey, isolates of an unknown Pythium sp. close to $P$. arrhenomanes with a unique combination of sporangial and oospore characteristics, and sequence data were repeatedly obtained from reed rhizosphere and leaf samples. This paper describes this species as Pythium phragmitis sp. nov., gives details on its morphology, physiology, ecology, and pathogenicity in comparison to similar species, and provides molecular evidence to support its status as a distinct species.

\section{MATERIAL AND METHODS}

\section{Sampling sites and procedures}

Soil samples for the recovery of Pythium spp. were taken from the rhizosphere of $P$. australis growing in the reed belt of the Lake Constance littoral between April and October 2003, and in December 2004. Sampling site 1 (Egg) is located on the southern shore of Bodan peninsula (Überlinger See, $9^{\circ} 11^{\prime} 18^{\prime \prime} \mathrm{E}$, $47^{\circ} 41^{\prime} 53^{\prime \prime} \mathrm{N}$ ), and surrounded by mixed alluvial forests. Site 2 (Reichenau) is located on the southern side of the Reichenau dam (Untersee, $9^{\circ} 06^{\prime} 04^{\prime \prime} \mathrm{E}$, $\left.47^{\circ} 41^{\prime} 15^{\prime \prime} \mathrm{N}\right)$. Both stands are considered heavily affected by flood induced reed dieback (Ostendorp et al. 2003). In total, 15 soil samples were taken from permanently flooded $(n=9)$ or from drier sites $(n=6)$ within the extension of the reed belt in stand 1 . In stand 2 , three samples from flooded reed sites were taken. Soil was collected in clean plastic bags, brought to the laboratory, and stored cool $\left(6^{\circ} \mathrm{C}\right)$ until further use. Soil samples were subjected to a standard bait test using oak leaflets (Quercus robur, greenhouse plants; Nechwatal \& Oßwald 2001), young reed seedlings (in vitro grown from seed) or grass leaf blades (boiled for $10 \mathrm{~min}$ ) as baits. $C a 0.251$ of each soil sample was flooded with deionised water, and several baits were spread over the water surface. Infected baits showing discolouration after $c a 3-5 \mathrm{~d}$ of incubation at $19^{\circ}$ were blotted dry on sterile filter paper, cut into segments, and plated onto a selective agar medium inhibiting growth of fungi other than oomycetes (16 g agar, $3 \mathrm{~g}$ $\mathrm{CaCO}_{3}, 100 \mathrm{ml} \mathrm{V8}$ juice, $900 \mathrm{ml} \mathrm{H}_{2} \mathrm{O}$ dest., amended with $25 \mathrm{mg}^{-1}$ benomyl, $50 \mathrm{mg}^{-1} \mathrm{PCNB}, 10 \mathrm{mg} \mathrm{1}^{-1}$ rifampicin, $200 \mathrm{mg}^{-1}$ ampicillin, 0,05 $\mathrm{ml}^{-1}$ nystatin, [PARPN], Tsao 1983). Plates were incubated at $19^{\circ}$ in the dark. Developing cultures were transferred to V8 agar plates (V8A, $100 \mathrm{ml} \mathrm{V8} \mathrm{juice,} 16 \mathrm{~g}$ Agar, $3 \mathrm{~g}$ $\mathrm{CaCO}_{3}, 900 \mathrm{ml} \mathrm{H}_{2} \mathrm{O}$ dest.) for further identification and maintenance. For the isolation from symptomatic reed plants, several mature leaves showing yellowing or necroses were collected from the same location (site 1) on three occasions during June 2004. Symptoms usually were found on those parts of the blades that had become inundated due to rising summer water levels. Leaves were thoroughly washed under running tap water, and surface disinfected with $70 \%$ ethanol (1 min). Small segments (ca $4 \mathrm{~mm}$ diam) from the margins between healthy and diseased tissue were plated onto PARPN, and further processed as described above.

\section{Growth and morphology}

For the assessment of growth rates isolates of Pythium phragmitis and related Pythium spp. (Table 1) were grown on $20 \mathrm{ml}$ corn meal agar (CMA, van der PlaatsNiterink 1981), malt extract agar (MEA, with $2 \%$ malt extract and $2 \%$ agar), and V8A in $90 \mathrm{~mm}$ Petri dishes, and incubated at $6,15,19,25,30,34,37$ and $40^{\circ}$ for $3 \mathrm{~d}$ after the onset of hyphal growth. Colony morphology was recorded after incubation for $6 \mathrm{~d}$ at $19^{\circ}$ in the dark. Investigations on sporangial development and germination behaviour were made on discs (diam $5 \mathrm{~mm}$ ) cut from the edge of a culture actively growing on V8A or CMA, and floated in demineralised water (DW) or non-sterile soil extract water (SEW) for $24 \mathrm{~h}$ at $20^{\circ}$ or $6^{\circ}$. Oogonial, antheridial, and oospore characteristics were determined after several days of incubation at $20^{\circ}$ in the dark on cultures prepared of V8A and CMA. Dimensions of 25 mature oogonia/ oospores chosen at random were recorded at $320 \times$ magnification with the light microscope.

\section{Sequence analysis}

In order to determine the phylogenetic relationship of the new species to those already known, sequence analyses of the ITS regions of the rDNA repeats and the cytochrome oxidase II ( cox II) gene were performed and data compared to those of related species. These sequences were either generated during this study or obtained from GenBank. For DNA isolation, mycelial material was scraped off from agar plates and extracted using the DNeasy Plant Mini Kit (Qiagen, Hilden, Germany), according to the manufacturer's instructions. All sequence editing and aligning was carried out using BioEdit, version 7.0.1 (http://www.mbio. ncsu.edu/BioEdit/bioedit.html). 
Table 1. Pythium species and isolates used in this study.

\begin{tabular}{|c|c|c|c|c|c|c|c|}
\hline Pythium sp. & Clade $^{\mathrm{a}}$ & Internal ID & Other ID & $\begin{array}{l}\text { ITS GenBank } \\
\text { accession No. }\end{array}$ & $\begin{array}{l}\text { Location, country, year } \\
\text { of isolation }\end{array}$ & Isolated from ${ }^{\mathrm{b}}$ & Source ${ }^{c}$ \\
\hline \multirow[t]{15}{*}{$P$. phragmitis } & \multirow[t]{15}{*}{ B1e } & P13 & CBS 117104 & AY 594259 & Egg, D, 2003 & Phragmites australis, s & UKN \\
\hline & & P40 & - & - & Egg, D, 2003 & P. australis, $\mathrm{s}$ & UKN \\
\hline & & P42 & - & - & Egg, D, 2003 & P. australis, $\mathrm{s}$ & UKN \\
\hline & & P52 & - & - & Egg, D, 2003 & P. australis, $\mathrm{s}$ & UKN \\
\hline & & P55 & - & - & Egg, D, 2003 & P. australis, $\mathrm{s}$ & UKN \\
\hline & & P58 & - & - & Egg, D, 2003 & P. australis, 1 & UKN \\
\hline & & P59 & - & - & Egg, D, 2004 & P. australis, 1 & UKN \\
\hline & & P61 & - & - & Egg, D, 2004 & P. australis, 1 & UKN \\
\hline & & P62 & - & - & Egg, D, 2004 & P. australis, 1 & UKN \\
\hline & & P63 & - & - & Egg, D, 2004 & P. australis, 1 & UKN \\
\hline & & P64 & - & - & Egg, D, 2004 & P. australis, 1 & UKN \\
\hline & & P65 & - & - & Egg, D, 2004 & P. australis, 1 & UKN \\
\hline & & P69 & - & - & Egg, D, 2003 & P. australis, $\mathrm{s}$ & UKN \\
\hline & & P71 & - & - & Reichenau, D, 2004 & P. australis, $\mathrm{s}$ & UKN \\
\hline & & P73 & - & - & Reichenau, D, 2004 & P. australis, $\mathrm{s}$ & UKN \\
\hline \multirow[t]{4}{*}{ P. arrhenomanes } & \multirow[t]{4}{*}{ B1e } & - & CBS324.62 & AY858635 & USA, 1962 & Zea mays & CBS \\
\hline & & - & CBS430.86 & - & NL, 1986 & Z. mays & CBS \\
\hline & & - & OPU480 & - & Japan, 2001 & Oryza sp. & OPU \\
\hline & & P54 & - & AY743661 & Konstanz, D, 2003 & P. australis, $\mathrm{s}$ & UKN \\
\hline P. graminicola & B1d & - & 70406 & - & Stuttgart, D, 1997 & Rhapis sp. & BBA \\
\hline \multirow[t]{2}{*}{ P. myriotylum } & \multirow[t]{2}{*}{ B1c } & - & OPU715 & - & Japan, 2004 & Phaseolus sp. & OPU \\
\hline & & - & CBS162.68 & - & USA, 1962 & Chrysanthemum sp. & CBS \\
\hline P. torulosum & Bla & - & OPU511 & - & Japan, 1989 & Agrostis sp. & OPU \\
\hline P. vanterpoolii & B1e & - & OPU512 & - & Japan, 1989 & Agrostis sp. & OPU \\
\hline
\end{tabular}

a Phylogenetic clade according to Lévesque \& De Cock (2004).

b s, soil sample; 1, leaf sample.

c BBA, Federal Biological Research Centre for Agriculture and Forestry - Microbiology, Berlin (Helgard Nirenberg); CBS, Centraalbureau voor Schimmelcultures, Utrecht; OPU, Osaka Prefecture University, Japan (Motoaki Tojo); UKN, Universität Konstanz, Phytopathology, Konstanz, Germany.

${ }^{\mathrm{d}}$ Isolate CBS 162.68 is deposited at CBS as P. aristosporum.

\section{$\operatorname{ITS} r D N A$}

PCR amplification of ITS1, 5.8S and ITS2 regions was performed with primer pair ITS4 (White et al. 1990) and ITS6 (Cooke \& Duncan 1997). Direct sequencing of the PCR products was carried out by MWG Biotech (Ebersberg, Germany), and boundaries of the ITS1, 5.8S and ITS2 regions determined according to Cooke et al. (2000). Sequence entries of Pythium spp. from clade B1e of Lévesque \& de Cock (2004) and $P$. graminicola (B1d) were retrieved from GenBank. $P$. aphanidermatum (clade A) was used as an outgroup. Sequence data were analysed and neighbour-joining phylogenetic analyses conducted using the programs DNADIST and NEIGHBOR from the PHYLIP package (v. 3.5, Felsenstein 1993), as described in Cooke et al. (2000). Kimura-2-parameter distances were calculated, with a transition/transversion ratio of 2.0. Tree topology was tested with 1000 bootstrap trials using SEQBOOT and CONSENSE (Felsenstein 1993). Trees were drawn using TreeView (Page 1996).

\section{cox II gene DNA}

To confirm the ITS sequence results and to separate Pythium phragmitis from its closest relative $P$. arrhenomanes, additional analysis of the cox II gene was performed. Fragments were generated using the primers FM35 and FM58 as described by Martin
(2000). Using these primers, direct sequencing was carried out by MWG Biotech. All cox II sequence data from $P$. arrhenomanes and $P$. aristosporum available in GenBank were used for phylogenetic analysis, as described for rDNA ITS regions. The sequence for $P$. arrhenomanes strain CBS 324.62 was newly generated in this study. Sequences were trimmed to a length of $563 \mathrm{bp}$ to match the length of most of these GenBank entries. Again, P. aphanidermatum was used as an outgroup.

\section{Pathogenicity}

Pathogenicity of five isolates of Pythium phragmitis was evaluated in comparison to that of five closely related species, i.e. $P$. arrhenomanes (four isolates) $P$. graminicola, $P$. myriotylum, $P$. torulosum, and $P$. vanterpoolii (one isolate each) (Tables 3-4).

\section{Pathogenicity towards reed seedlings}

Pathogenicity towards reed seedlings was assessed in a small-scale soil infestation test. Petri dishes (60 mm diam) were filled with $c a 2.5 \mathrm{~g}$ autoclaved, moist wheat kernels ( $c a 25$ kernels). These were inoculated with a V8 agar disc colonised with the Pythium sp. to be tested. When the culture completely covered the wheat kernels (depending on growth rate), 
Table 2. Morphological and growth features of Pythium spp. examined.

\begin{tabular}{|c|c|c|c|c|c|c|c|}
\hline $\begin{array}{l}\text { Pythium sp. } \\
\left(\text { clade }^{\mathrm{a}}\right)\end{array}$ & $\begin{array}{l}\text { No. of } \\
\text { isolates }\end{array}$ & $\begin{array}{l}\text { (a) Culture morphology } \\
\text { (b) Aerial mycelium } \\
\text { (on V8A) }\end{array}$ & $\begin{array}{l}\text { Growth rate } \\
\left(\text { V8A) at } 30^{\circ} \mathrm{C}\right. \\
{\left[\mathrm{mm} \mathrm{d}^{-1}\right]^{\mathrm{b}}}\end{array}$ & $\begin{array}{l}\text { Maximum } \\
\text { temp. for } \\
\text { growth }\left({ }^{\circ} \mathrm{C}\right)\end{array}$ & $\begin{array}{l}\text { Oospore diam } \\
(\mu \mathrm{m})^{\mathrm{b}}\end{array}$ & $\begin{array}{l}\text { Oospore } \\
\text { state }\end{array}$ & $\begin{array}{l}\text { Oospore } \\
\text { abortion }^{\mathrm{c}}\end{array}$ \\
\hline P. phragmitis (B1e) & 15 & $\begin{array}{l}\text { (a) no specific pattern } \\
\text { (b) cottony }\end{array}$ & $30.9(29.5-33)$ & 40 & $25(23.5-26.5)$ & plerotic & - \\
\hline P. arrhenomanes (B1e) & 3 & $\begin{array}{l}\text { (a) no specific pattern } \\
\text { (b) cottony, loose }\end{array}$ & $25.7(23-27.0)$ & $<40$ & $32(31.5-32.5)$ & plerotic & ++ \\
\hline P. arrhenomanes P54 (B1e) & 1 & $\begin{array}{l}\text { (a) no specific pattern } \\
\text { (b) dense-cottony }\end{array}$ & $36(\mathrm{n} / \mathrm{a})$ & $>40$ & $\mathrm{n} / \mathrm{a}$ & $\mathrm{n} / \mathrm{a}$ & $\mathrm{n} / \mathrm{a}$ \\
\hline P. vanterpoolii (B1e) & 1 & $\begin{array}{l}\text { (a) no specific pattern } \\
\text { (b) cottoy-appressed }\end{array}$ & $13.5(\mathrm{n} / \mathrm{a})$ & 30 & $20(\mathrm{n} / \mathrm{a})$ & plerotic & - \\
\hline P. graminicola $(\mathrm{B} 1 \mathrm{~d})$ & 1 & $\begin{array}{l}\text { (a) no specific pattern } \\
\text { (b) scarce }\end{array}$ & $25(\mathrm{n} / \mathrm{a})$ & $>40$ & $23.5(\mathrm{n} / \mathrm{a})$ & plerotic/aplerotic & ++ \\
\hline P. myriotylum (B1c) & 2 & $\begin{array}{l}\text { (a) no specific pattern } \\
\text { (b) cottony, loose }\end{array}$ & $46.5(39-54)$ & $>40$ & $25.5(25-26.5)$ & aplerotic & + \\
\hline P. torulosum (B1a) & 1 & $\begin{array}{l}\text { (a) stellate-rosette } \\
\text { (b) none }\end{array}$ & $16(\mathrm{n} / \mathrm{a})$ & 37 & 17.5 (n/a) & plerotic & - \\
\hline
\end{tabular}

the Petri dishes were filled with a non-sterile mixture of sand and potting soil, watered, and 10 reed seedlings ( $2 \mathrm{wk}$ old) were planted into the soil. Control plants grew on a non-inoculated wheat/substrate mixture. Seedling experiments were performed in duplicate. Number of dead plants was noted after $4 \mathrm{~d}$ incubation at $19^{\circ}$ under natural light.

\section{Pathogenicity towards reed and maize leaves}

Six month old greenhouse-grown reed and 4 wk old maize plants (Zea mays) were used for the assessment of the pathogenicity towards mature leaves. For each isolate, seven leaves of approximately the same age (i.e. the same position on the culm) were collected, clipped on base and apex (length $c a 12-15 \mathrm{~cm}$ ), and placed in glass Petri dishes containing moist filter paper. Clipped edges were sealed with paraffin wax to avoid infection through these large wounds. Leaf blades were inoculated with a disc (4 mm diam) taken from the margin of an actively growing V8A culture of each of the Pythium spp. tested. A drop of a $0.05 \%$ skimmed milk solution was applied to the agar to facilitate adhesion to the leaf surface. Controls received uncolonised V8A plugs. Experiments were conducted in triplicate for each test plant. Leaf lesion length (longitudinal extension) was recorded after $3 \mathrm{~d}$ (maize) or $6 \mathrm{~d}$ (reed) of incubation at $19^{\circ}$.

\section{RESULTS}

\section{Distribution}

In total, 13 isolates of Pythium phragmitis were obtained from site 1 . The species was recovered from 6 out of 9 soil samples from flooded sites, but was not found in any of the soil samples from drier sites. It was also readily isolated from all symptomatic mature reed leaves collected in stand 1 , revealing 7 additional isolates. In site 2, P. phragmitis was isolated from 2 out of 3 flooded soil samples (Table 1). Isolation from soil was successful during the whole sampling period (April-December). The species was exclusively caught with young reed seedlings as baits, while it was never recovered from other grass blades or oak baits.

\section{Growth and morphology}

All isolates of Pythium phragmitis with an optimum growth temperature of $30^{\circ}$ on all agar media. Maximum growth temperature $c a 40^{\circ}$. Growth rates at $30^{\circ}$ on V8A in comparison to other species are given in Table 2. Colonies without a specific growth pattern, showing various amounts of dense or loose cottony aerial mycelium on V8A, CMA and MEA.

Main hyphae to $7 \mu \mathrm{m}$ wide. Hyphal swellings or chlamydospores not observed. Sporangia not observed on solid agar, but readily produced in water or SEW culture, consisting of irregularly lobulate, inflated filamentous ( $\mathrm{ca} 10-15 \mu \mathrm{m}$ wide) and knot-like, branched elements (Figs 1-3). Zoospore release observed only in very few isolates under the conditions applied, with low numbers of zoospores being released. Oogonia abundantly produced in single culture, strictly globose, smooth-walled, and borne terminally. Mean oogonial diameter of six isolates ranging from 23.5 to $26.5 \mu \mathrm{m}$ (mean $25 \mu \mathrm{m}$, Table 2). Antheridia usually monoclinous, often also diclinous, usually crooknecked, 1-5 (8) per oogonium, making broad apical contact to the oogonium. Antheridial cells measuring ca $10-11 \times 6-7 \mu \mathrm{m}$ (means of six isolates). Oospores single, plerotic, completely filling the oogonium, and oospore diameters not significantly different from oogonial diameters. Oospore walls up to $2.5 \mu \mathrm{m}$ thick (Figs 4-12). Levels of oospore abortion low in all isolates. 

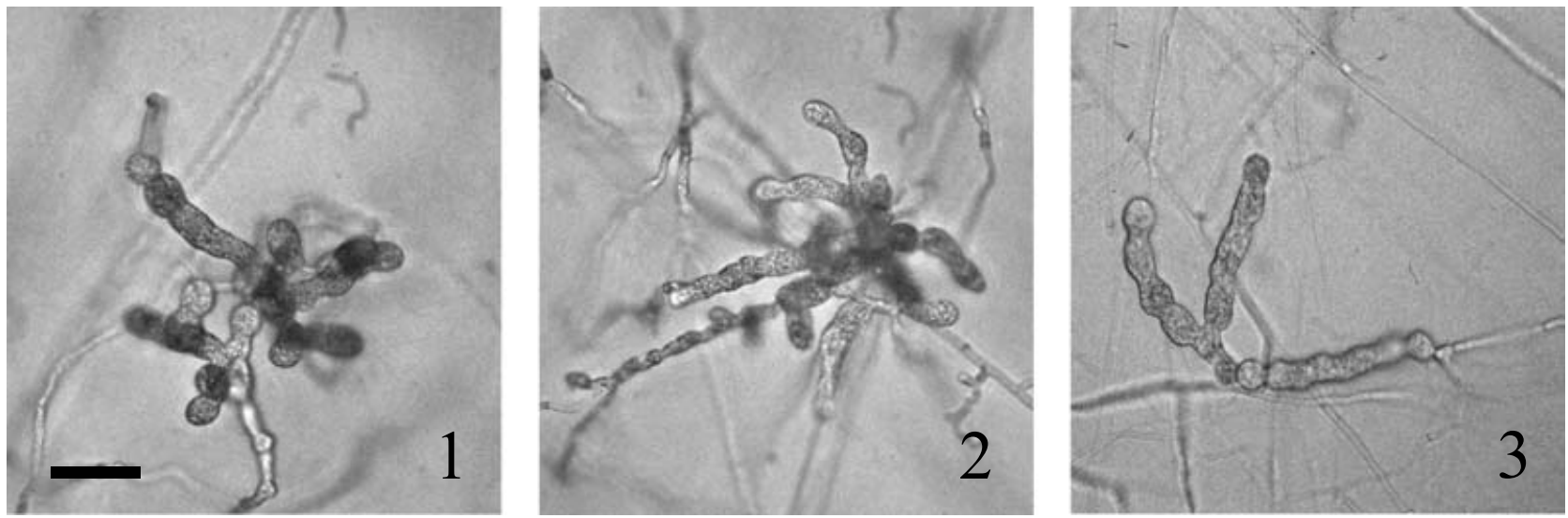

Figs 1-3. Sporangia of Pythium phragmitis consisting of irregularly lobulate, inflated filamentous elements. Bar $=40 \mu \mathrm{m}$.
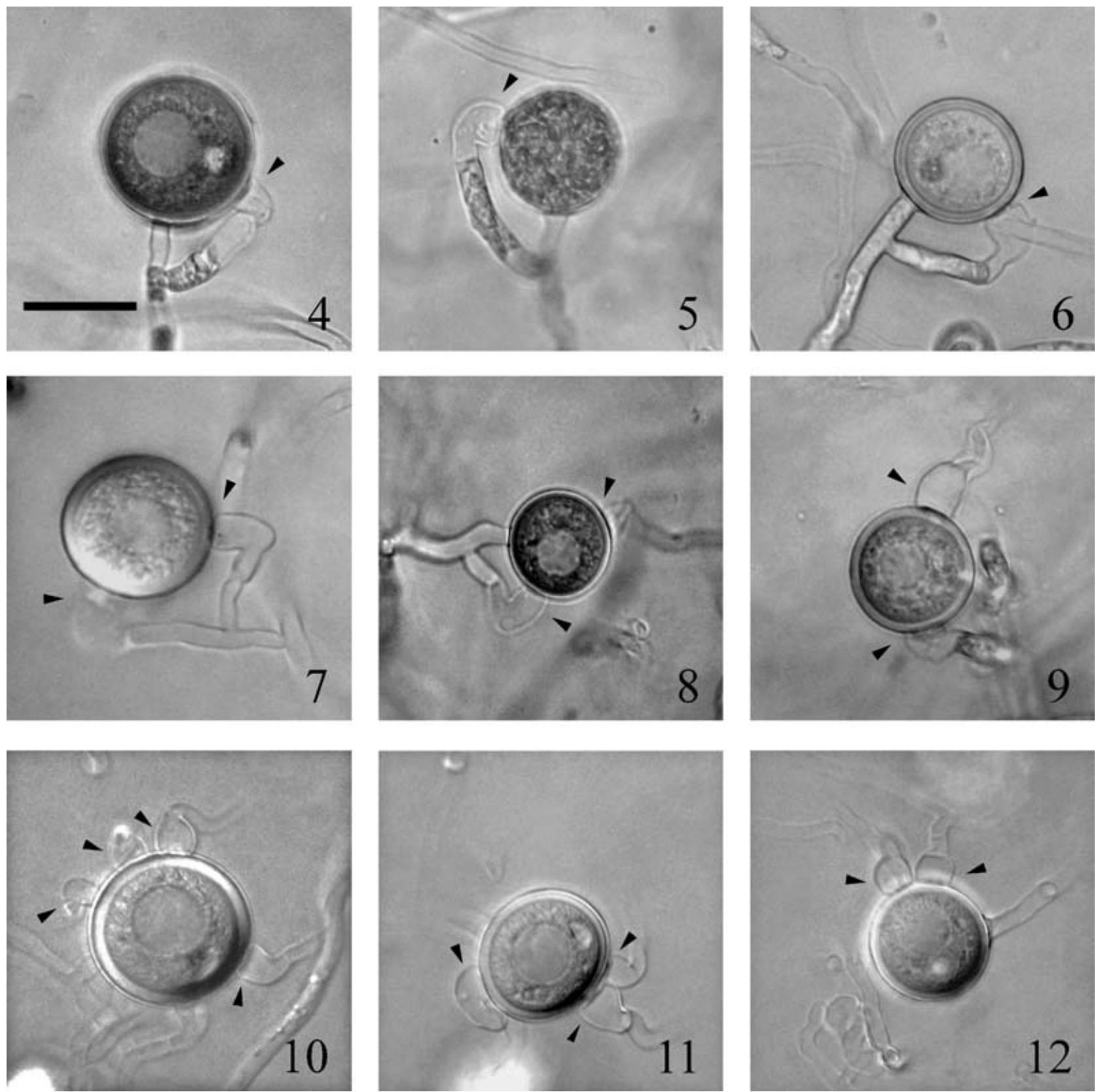

Figs 4-12. Oogonia, oospores and antheridia (arrowheads) of Pythium phragmitis. Figs 4-6. Oogonia/oospores with single, monoclinous antheridia. Figs 7-9. Oogonia/oospores with two mono- or diclinous antheridia. Figs 10-12. Oogonia/oospores with two or more, mostly diclinous antheridia. Bar $=20 \mu \mathrm{m}$. 


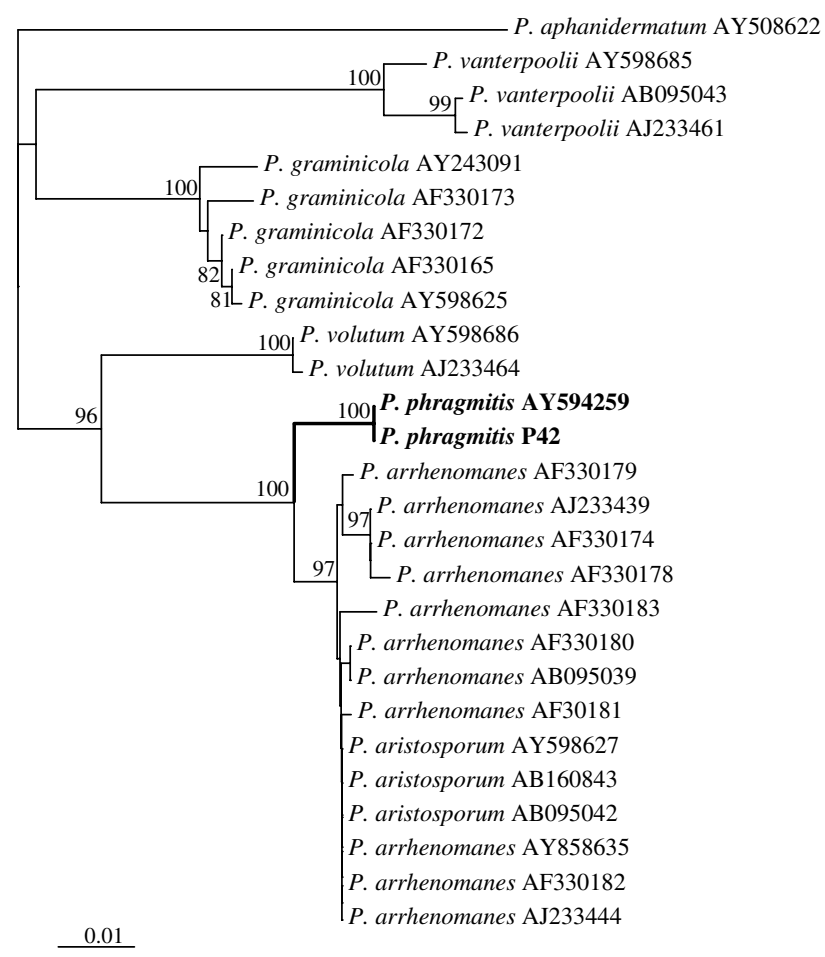

Fig. 13. Phylogenetic tree of Pythium spp. from clade B1e of Lévesque \& de Cock (2004), including P. phragmitis, and $P$. graminicola constructed after distance-based analysis of ITS1, 5.8S and ITS2 regions of the rDNA. If available, GenBank accession numbers are given. Numbers at the branches indicate the percentage of bootstrap values after 1000 replications (values below $50 \%$ not shown). P. aphanidermatum was used as an outgroup. Bar=number of nucleotide substitutions per site.

\section{Sequence analysis}

ITS sequences

All 15 isolates of Pythium phragmitis had identical ITS sequences with the length of the complete ITS1, $5.8 \mathrm{~S}$ and ITS2 being $796 \mathrm{bp}$. The sequence has been submitted to GenBank (AY594259). BLAST searches indicated the species' close relatedness to $P$. arrhenomanes. The sequence was $98 \%$ identical to most GenBank database entries for this species (e.g. AY858635 =CBS 324.62, ex-type strain of P. arrhenomanes), corresponding to $13 \mathrm{bp}$ difference. Two more $98 \%$ matches were observed with 3 entries for P. aristosporum and with another P. graminicola (AY099310), while it was clearly different from that of most other P. graminicola entries (e.g. AY598625=CBS 327.62, $89 \%$ identity). Neighbour-joining phylogenetic analysis of the ITS sequence data confirmed the distinctness of the new species from P. arrhenomanes (Fig. 13) with high bootstrap values.

\section{cox II gene DNA}

There was no sequence diversity within the cox II sequence of 15 Pythium phragmitis isolates, and the

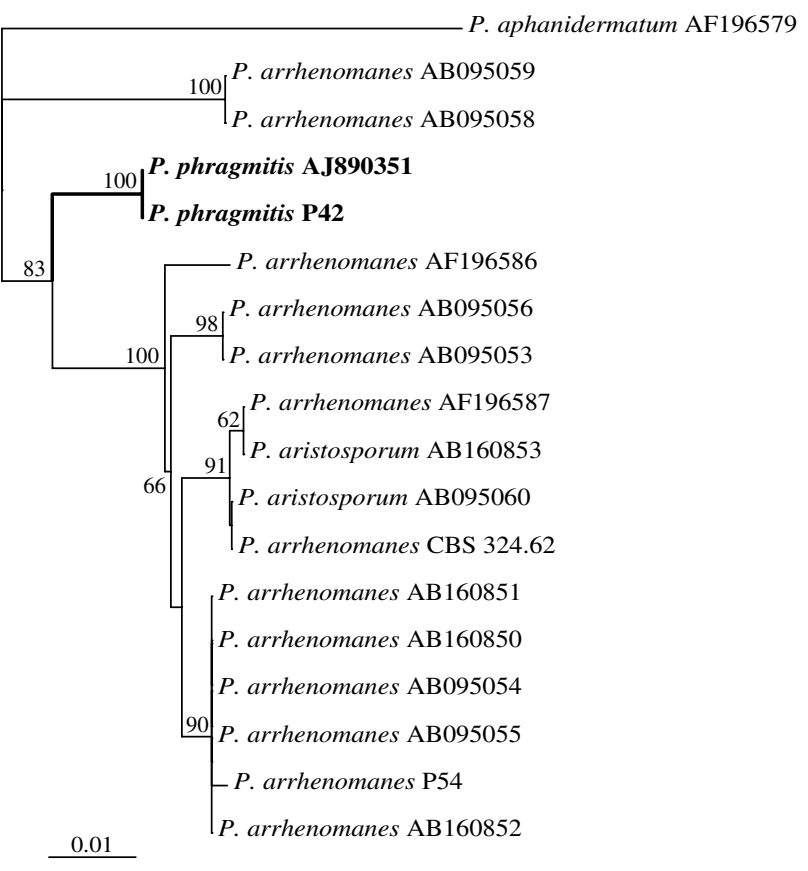

Fig. 14. Phylogenetic tree of Pythium arrhenomanes, $P$. aristosporum and $P$. phragmitis, constructed after distance-based analysis of sequences of the cytochrome oxidase II gene. If available, GenBank accession numbers are given. Numbers at the branches indicate the percentage of bootstrap values after 1000 replications (values below $60 \%$ not shown). $P$. aphanidermatum was used as an outgroup. $\mathrm{Bar}=$ number of nucleotide substitutions per site.

sequence has been submitted to EMBL (AJ890351). Similarly, all but two P. arrhenomanes GenBank entries for this gene differed by only $0.86 \%$. In contrast, sequence divergence between the type strains of $P$. phragmitis and P. arrhenomanes was $3.1 \%$ (17 positions). Phylogenetic analysis confirmed that $P$. phragmitis isolates did not cluster within the majority of $P$. arrhenomanes isolates, but on a separate branch, supported by high bootstrap values (Fig. 14).

\section{Pathogenicity}

\section{Pathogenicity towards reed seedlings}

All isolates of $P$. phragmitis were pathogenic on Phragmites seedlings. Sixty to $100 \%$ of the plantlets infected with this species were dead after $4 \mathrm{~d}$ of incubation (Table 3). The isolates of $P$. graminicola and $P$. myriotylum were equally aggressive towards reed seedlings. Mortality caused by $P$. arrhenomanes in our tests was lower (30-70\% after $4 \mathrm{~d}$, Table 3$)$. $P$. vanterpoolii and $P$. torulosum caused minor damage to the seedlings. Controls did not show any damage, nor plant death during the course of the experiment.

\section{Pathogenicity towards reed and maize leaves}

All isolates of Pythium phragmitis caused extensive necroses on both maize and reed leaves after 3 or $6 \mathrm{~d}$ 
Table 3. Reed seedling mortality caused by Pythium phragmitis and related species. Mean and range of two replicate experiments is given, with each experiment consisting of 10 seedlings per isolate.

\begin{tabular}{lc}
\hline $\begin{array}{l}\text { Pythium sp. } \\
\text { (no. of isolates tested) }\end{array}$ & $\begin{array}{l}\text { Mean seedling mortality } \\
\text { (range) }(\%)\end{array}$ \\
\hline P. phragmitis (5) & $79(70-88)$ \\
P. arrhenomanes $(4)$ & $58(43-70)$ \\
P. vanterpoolii $(1)$ & $15(0-30)$ \\
P. graminicola $(1)$ & $75(70-80)$ \\
P. myriotylum (1) & 100 \\
P. torulosum (1) & $5(0-10)$ \\
Control & 0 \\
\hline
\end{tabular}

incubation, respectively. On reed, they were consistently more aggressive than isolates of $P$. arrhenomanes, $P$. graminicola, $P$. myriotylum, $P$. torulosum and $P$. vanterpoolii in all tests. Necroses caused by $P$. phragmitis were significantly larger on this plant species (Table 4). P. phragmitis was readily re-isolated from infected reed leaves. In maize, no such clear-cut differences in virulence were observed, and $P$. phragmitis, $P$. arrhenomanes, and $P$. graminicola were equally aggressive (Table 4). Mock inoculated control leaves did not show any lesions.

\section{TAXONOMY}

Pythium phragmitis J. Nechwatal, sp. nov.

Etym.: Named after its potential host plant, Phragmites australis

Coloniae crescentes celeres in agaris 'V8A', 'MEA' et 'CMA'. Crescunt in omnibus agaris inter 5 et $40^{\circ} \mathrm{C}$, optime ad $30^{\circ}$, cum incrementum radiatum quotidianum $30.5 \mathrm{~mm}$ in agaro 'V8A'. Coloniae pubescentes, cum mycelio aerio, sine ordinatione distincto in omnibus agaris. Hyphae hyalinae, non-septatae, primariae ad $7 \mu \mathrm{m}$ latae. Chlamydosporae vel inflationes hypharum non observatae. Sporangia formata abundantia in cultura aqua submerso, terminalia aut intercalaria, filamentosa et inflata, cum multis nodibus, plerumque ramosa, in medio $10-15 \mu \mathrm{m}$ lata. Zoosporae raro formatae ad 20 aut $6^{\circ}$. Culturae homothallicae, oogoniis et oosporis abundantibus in agaro 'V8A' vel 'CMA'. Oogonia terminalia, globosa, cum paries nonornatus, in medio $25.9 \mu \mathrm{m}(22.0-30.0 \mu \mathrm{m})$ in diametro. Antheridia 1-5 (8) per oogonio, monoclina vel diclina, clavata, saepe curvata $(9-12 \times 5-8 \mu \mathrm{m})$, apices cum oogonia late coniuncta. Oosporae singularia, globosae, pleroticae, paries $1.5-2.5 \mu \mathrm{m}$ crassus.

Typus: Germany: Konstanz/Egg, $9^{\circ} 11^{\prime} 18^{\prime \prime} \mathrm{E}, 47^{\circ} 41^{\prime}$ $53^{\prime \prime} \mathrm{N}$, isol. ex solo rhizosphaerae ad Phragmites australis 1, July 2003, J. Nechwatal, UKN P13 (dried culture)holotypus; CBS 117104 - ex-type culture.

Colonies fast growing on V8A, MEA and CMA; growth observed between 5 and $40^{\circ}$ on all agar media, optimum at $30^{\circ}$, with daily growth of $30.5 \mathrm{~mm}$ on V8A. Colonies cottony, with aerial mycelium, without a distinct growth pattern. Hyphae hyaline, nonseptate, up to $7 \mu \mathrm{m}$ wide. Chlamydospores or hyphal
Table 4. Lesions caused by Pythium phragmitis and related species on leaves of reed and maize. Mean lesion length (SEM) of three replicate experiments is given, with each experiment consisting of seven leaves per isolate. Means within each plant species followed by the same letter are not significantly different $(P<0.05$, Kruskal-Wallis test, Dunn's Multiple Comparison Test).

\begin{tabular}{llll}
\hline $\begin{array}{l}\text { Plant } \\
\text { species }\end{array}$ & $\begin{array}{l}\text { Pythium sp. } \\
\text { (no. of isolates tested) }\end{array}$ & $\begin{array}{l}\text { Mean lesion } \\
\text { length }(\mathrm{cm})\end{array}$ & SEM \\
\hline Reed & P. phragmitis (5) & $1.8 \mathrm{a}$ & 0.12 \\
& P. arrhenomanes (4) & $0.6 \mathrm{~b}$ & 0.05 \\
& P. vanterpoolii (1) & $0.2 \mathrm{~cd}$ & 0.12 \\
& P. graminicola $(1)$ & $0.4 \mathrm{bc}$ & 0.07 \\
& P. myriotylum (1) & $0.2 \mathrm{~cd}$ & 0.05 \\
& P. torulosum (1) & $0.1 \mathrm{~d}$ & 0.03 \\
& Control & $0.0 \mathrm{~d}$ & 0.0 \\
Maize & P. phragmitis (5) & $4.9 \mathrm{a}$ & 0.29 \\
& P. arrhenomanes $(4)$ & $4.3 \mathrm{a}$ & 0.27 \\
& P. vanterpoolii (1) & $1.7 \mathrm{~b}$ & 0.45 \\
& P. graminicola $(1)$ & $4.6 \mathrm{a}$ & 0.26 \\
& P. myriotylum $(1)$ & $1.9 \mathrm{~b}$ & 0.48 \\
& P. torulosum $(1)$ & $1.1 \mathrm{~b}$ & 0.25 \\
& Control & $0.0 \mathrm{~b}$ & 0.0 \\
\hline
\end{tabular}

swellings not observed. Sporangia abundantly produced in water culture, terminal or intercalary, consisting of inflated filamentous and knot-like, branched elements, $10-15 \mu \mathrm{m}$ wide. Zoospores rarely formed at 20 or $6^{\circ}$. Cultures homothallic, oogonia and oospores abundantly produced in V8A or CMA. Oogonia terminal, globose, smooth-walled, 22-30 $\mu \mathrm{m}$ (mean $25.9 \mu \mathrm{m})$ diam. Antheridia 1-5 (8) per oogonium, monoclinous or diclinous, clavate, crook-necked, 9-12 $\times 5-8 \mu \mathrm{m}$, making broad apical contact with oogonia. Oospores single, globose, plerotic; wall $1.5-2.5 \mu \mathrm{m}$ wide.

\section{DISCUSSION}

This study reports on the presence of a new Pythium sp. in reed stands of Lake Constance. Pythium phragmitis is a fast growing, homothallic species with inflated filamentous sporangia belonging to the $P$. graminicola complex (Hendrix \& Papa 1974), or clade Ble of Lévesque \& de Cock (2004), respectively. Although closely related to the species in these groups, $P$. phragmitis can still be easily distinguished by its unique combination of morphological characters (Table 2), pathogenicity (Tables 3-4), and DNA sequence data.

$P$. arrhenomanes, an economically important cereal pathogen, is the new species' closest relative, showing 98 or $97 \%$ identity in the ITS and cox II sequences, respectively. As indicated by literature data (Drechsler 1928, Rands \& Dopp 1934, van der Plaats-Niterink 1981, Kröber 1985), and comparison to reference strains (Table 2), it is distinguished from $P$. phragmitis by several traits: it usually has larger oogonia/ oospores, more antheridia per oogonium (15-20) which are usually diclinous, and shows either high levels of oospore abortion or completely fails to form oogonia 
and oospores. Although growth rate of $P$. arrhenomanes in our study was very variable (a fact that has also been reported by Rands \& Dopp 1934), three out of four strains grew markedly slower than $P$. phragmitis (Table 2). Furthermore, all isolates regardless of their origin and age were significantly less aggressive towards reed as compared to P. phragmitis (Tables 3-4), indicating different virulence levels of the two species. High degrees of intraspecific variability in growth rate, morphology and virulence have already been described to occur in $P$. arrhenomanes in the past. In the 1930s, three varieties of $P$. arrhenomanes have been erected (Waterhouse 1968), and Rands \& Dopp (1934) considered $P$. arrhenomanes to be a highly variable species, suggesting several 'morphologic strains'. Chen \& Hoy (1993) studied 40 isolates of the species and found a large proportion of them to have smaller oogonia and less antheridia (as in $P$. phragmitis) than originally reported. Based on ITS-RFLP differences, three molecular $P$. arrhenomanes subgroups were erected. However, these were not consistent with oospore diameter data and no further taxonomical reference is being made to them. After in silico digests with the respective enzymes, we could rule out a potential congruence of any of these groups with $P$. phragmitis. Matsumoto et al. (2000), in contrast, suggested that $P$. irregulare isolates showing consistent ITS sequence and morphological divergence probably are distinct species. In the case of $P$. phragmitis, cox II sequences corroborated the ITS results, clearly placing the taxon distinct from $P$. arrhenomanes. Therefore, at present knowledge and as evidenced by our morphological and sequence data, we propose $P$. phragmitis to represent a new species distinct from $P$. arrhenomanes. Different levels of virulence towards reed as observed in our tests add further weight to this taxonomical implication.

$P$. aristosporum is considered a species very close to $P$. arrhenomanes. It is only distinguished by the number and origin of the antheridia (van der PlaatsNiterink 1981). Three out of four ITS GenBank entries for this species (AB095042, AY598627, AB160843) were identical to $P$. arrhenomanes (e.g. AY858635, ex-type), so that it remains doubtful whether P. aristosporum is a distinct species. Although it seems generally accepted not only in the genus Pythium that ITS sequence identity does not prove conspecificity (Lévesque \& de Cock 2004), the fact that cox II sequences also placed $P$. aristosporum within $P$. arrhenomanes (Fig. 14) cast doubt on this taxon being a distinct species. According to BLAST searches with ITS sequence data produced in our study, and Arthur W. A. M. de Cock (pers. comm.), the P. aristosporum isolate studied here (CBS 162.68, Table 1), is a misidentified $P$. myriotylum with which it also shared growth rate, temperature maximum and oospore characteristics (Table 2). Similarly, in BLAST searches the fourth GenBank entry for $P$. aristosporum (AF290844) found its closest match in P. myriotylum.
$P$. graminicola, another related grass pathogen (clade B1d) has also been considered difficult to separate from $P$. arrhenomanes in the past, due to overlapping morphological characters (Chen \& Hoy 1993, Gilbert, Cother \& Nicol 1995). However, it could be clearly distinguished from this species by molecular evidence (Chen \& Hoy 1993). Although P. graminicola also shares several morphological traits with $P$. phragmitis (oogonial diameter, number and origin of antheridia, growth temperatures), ITS and cox II sequence differences readily separate these species (89 and $94 \%$ identity, respectively). A single ITS $98 \%$ match of P. phragmitis with P. graminicola (AY099310) is due to the misidentification of this isolate (Motoaki Tojo, pers. comm.). In addition, our observations as well as Kröber (1985) proved the presence of a significant number of aplerotic oospores in $P$. graminicola (Table 2).

$P$. vanterpoolii also clusters within clade B1e of Lévesque \& de Cock (2004). It differs considerably from $P$. phragmitis as to its morphology (Table 2), pathogenicity (Tables 3-4) and DNA sequence. It has sporangia consisting of rather irregularly catenulate globose, unbranched elements, its oogonia and oospores are smaller, with less antheridia, and it reaches its maximum growth temperature at $30^{\circ}$ (Table 2). ITS sequence similarity to $P$. phragmitis is $89 \%$. Similarly, P. volutum from clade B1e differs by morphology (long antheridial stalks coiling around oogonial stalks), growth temperature (maximum $31^{\circ}$; van der Plaats-Niterink 1981) and ITS sequence $(92 \%$ identity). P. torulosum (clade B1a) and P. myriotylum (clade B1c), two more grass associated species from the $P$. graminicola complex also differ distinctly from $P$. phragmitis in growth, morphology (Table 2 ; van der Plaats-Niterink 1981), pathogenicity (Tables 3-4) and ITS sequence ( $89 \%$ and $88 \%$ identity, respectively).

The new species $P$. phragmitis possibly plays an important role in reed stand ecology. A number of factors have been proposed as possible causes for the dieback of reed stands in European lakes (Ostendorp 1989, Brix 1999). A current study on the mechanisms of reed belt area losses in Lake Constance emphasised the importance of water level variation, and flooding of reed plants during high water levels was suggested to be among the main causes for the decline (Ostendorp et al. 2003, Dienst et al. 2004). The probability of a reed stand being severely damaged was shown to be significantly increasing with decreasing elevation relative to the mean water level. Although this could in part be explained by limited oxygen supply of shoots and rhizomes after flooding, other as yet unknown factors have been postulated to account for the damage observed (Ostendorp et al. 2003). Our results provide several strong lines of evidence for a close association of the proposed reed pathogen $P$. phragmitis with $P$. australis: (1) it was readily isolated from the majority of analysed reed rhizosphere soil samples; (2) it was exclusively caught with reed seedlings as baits 
and not with oak leaflets or boiled grass leaves; (3) it was consistently isolated from necrotic mature reed leaves in the field; and (4) a high level of virulence towards reed was demonstrated in in vitro infection assays where it was significantly more aggressive than related species. Koch's postulates have been fulfilled for $P$. phragmitis on $P$. australis leaves. Furthermore, these results are indicative of a considerable degree of specificity towards a single host species, a trait not generally established in the genus Pythium. Given its high virulence even against mature reed leaves, $P$. phragmitis infection of reed inundated during flooding events may be of particular significance. Although Pythium spp. are generally considered to be root pathogens, once present in a reed stand they will easily disperse and disseminate by means of zoospores, and infect submerged parts of reed plants. This is in accordance with the observation that mature reed leaves readily became necrotic on flooded parts, i.e. those parts of the blades that came in contact to the source of inoculum during rising water levels. Experiments with young reed plants flooded with $P$. phragmitis-infested water in vitro showed that virtually every unfolded submerged leaf died within several days, while this did not occur in flooded but uninoculated controls (J.N. \& A.W., unpubl.). Significant losses in assimilating leaf area will contribute to a decrease of carbohydrate storage in the rhizomes, reducing number and size of emerging shoots in the next growing period, and eventually resulting in a patchy appearance typical for declining reed stands (Brix 1999, Ostendorp et al. 2003).

Low rates of seedling establishment and the sensitivity of seedlings to submergence are well-established for $P$. australis, and seedling survival was suggested to be even lowered by lake water regulation, and the subsequent lack of periodically non-submerged natural seedbeds (Rea 1996, Mauchamp, Blanch \& Grillas 2001). In Lake Constance, a largely non-regulated lake with natural water regimes, the rate of generative propagation in reed stands is likely to diminish due to the high susceptibility of seedlings to $P$. phragmitis. As indicated by our infection tests and baiting procedures (with reed seedlings used as baits), even natural Pythium loads in littoral soils can negatively influence seedling survival. The resulting failure of generative reproduction (i.e. failure of 'pulse recruitment', Clevering \& Lissner 2000) could possibly prevent the re-colonisation of gaps, and subsequently lead to further opening of previously homogeneous reed stands. In addition, lack of generative offspring can reduce genetic diversity of reed on a landscape level, thus increasing a stand's vulnerability to biotic pests and long-term environmental changes (Rea 1996, Brix 1999, Clevering \& Lissner 2000). For example, water depth is considered one of the main selective forces in mature P. australis populations (Clevering \& Lissner 2000). As flooding events in Lake Constance are anticipated to occur more frequently and earlier during the growing period (Dienst et al. 2004), reed genotypes showing retarded shoot regrowth (Kühl et al. 1999) would possibly be able to escape negative effects of selective forces such as leaf submergence and Pythium infection. A higher incidence of generative propagation within reed stands would allow for natural selection in favour of such genotypes (Clevering \& Lissner 2000).

The results of our study indicate that $P$. phragmitis is able to cause damage to Lake Constance reed stands and should be considered as a contributing factor to decline phenomena that have repeatedly been reported for this lake. Further research should elucidate the distribution of the species on a more regional scale and eventually clarify its possible role in reed stand dynamics in other European lakes. In this context, more insight into the origin and evolution of the taxon will be of particular interest.

\section{ACKNOWLEDGEMENTS}

This study was funded by the Deutsche Forschungsgemeinschaft (DFG), as part of the SFB 454 ('Littoral Zone of Lake Constance'). We thank Helgard Nirenberg (BBA, Berlin) and Motoaki Tojo (OPU, Osaka) for providing isolates.

\section{REFERENCES}

Bán, R., Fischl, G. \& Virányi, F. (1996) A spatio-temporal analysis of fungal pathogens on reed in natural habitats. Acta Phytopathologica et Entomologica Hungarica 31: 219-227.

Brix, H. (1999) The European research project on reed die-back and progression (EUREED). Limnologica 29: 5-10.

Chen, W. \& Hoy, J. W. (1993) Molecular and morphological comparison of Pythium arrhenomanes and $P$. graminicola. Mycological Research 97: 1371-1378.

Clevering, O. A. \& Lissner, J. (2000) Taxonomy, chromosome numbers, clonal diversity and population dynamics of Phragmits australis. Aquatic Botany 64: 185-208.

Cooke, D. E. L., Drenth, A., Duncan, J. M., Wagels, G. \& Brasier, C. M. (2000) A molecular phylogeny of Phytophthora and related oomycetes. Fungal Genetics \& Biology 30: 17-32.

Cooke, D. E. L. \& Duncan, J. M. (1997) Phylogenetic analysis of Phytophthora species based on ITS1 and ITS2 sequences of the ribosomal RNA gene repeat. Mycological Research 101: 667-677.

Dienst, M., Schmieder, K. \& Ostendorp, W. (2004) Dynamik der Schilfröhrichte am Bodensee unter dem Einfluß von Wasserstandsvariationen. Limnologica 34: 29-36.

Drechsler, C. (1928) Pythium arrhenomanes n. sp., a parasite causing maize root rot. Phytopathology 18: 873-875.

Ernst, M., Mendgen, K. W. \& Wirsel, S. G. R. (2003) Endophytic fungal mutualists: seed-borne Stagonospora spp. enhance reed biomass production in axenic microcosms. Molecular PlantMicrobe Interactions 16: 580-587.

Felsenstein, J. (1993) PHYLIP (Phylogeny Inference Package). Version 3.5c. Department of Genetics, University of Washington, Seattle.

Gilbert, R. L., Cother, E. J. \& Nicol, H. I. (1995) Mathematical methods to compare growth curves of Pythium arrhenomanes and eleven other Pythium species as an aid to their identification. Mycological Research 99: 19-30.

Hallett, I. C. \& Dick, M. W. (1981) Seasonal and diurnal fluctuations of oomycete propagule numbers in the free water of a freshwater lake. Journal of Ecology 69: 671-692. 
Haslam, S. M. (1972) Biological Flora of the British Isles: Phragmites communis Trin. (Arundo phragmites L.,? Phragmites australis (Cav.) Trin. ex Steudel). Journal of Ecology 60: 585-610.

Hendrix, F. F. \& Campbell, W. A. (1973) Pythiums as plant pathogens. Annual Review of Phytopathology 11: 77-98.

Hendrix, F. F. \& Papa, K. E. (1974) Taxonomy and genetics of Pythium. Proceedings of the American Phytopathological Society 1: 200-207.

Honsell, M. (1879) Der Bodensee und die Tieferlegung seiner Hochwasserstände. Eine hydrologische Studie. Verlag Konrad Wittwer, Stuttgart.

Kröber, H. (1985) Erfahrungen mit Phytophthora de Bary und Pythium Pringsheim. Mitteilungen der Biologischen Bundesanstalt für Land- und Forstwirtschaft 225: 1-175.

Kühl, H., Koppitz, H., Rolletschek, H. \& Kohl, J.-G. (1999) Clone specific differences in a Phragmits australis stand I. Morphology, genetics and site description. Aquatic Botany 64: 235-246.

Lévesque, C. A. \& De Cock, A. W. A. M. (2004) Molecular phylogeny and taxonomy of the genus Pythium. Mycological Research 108: 1363-1383.

Martin, F. N. (2000) Phylogenetic relationships among some Pythium species inferred from sequence analysis of mitochondrially encoded cytochrome oxidase II gene. Mycologia 92: 711-727.

Matsumoto, C., Kageyama, K., Suga, H. \& Hyakumachi, M. (2000) Intraspecific DNA polymorphisms of Pythium irregulare. Mycological Research 104: 1333-1341.

Mauchamp, A., Blanch, S. \& Grillas, P. (2001) Effects of submergence on the growth of Phragmites australis seedlings. Aquatic Botany 69: 147-164.

Mills, K. E. \& Bever, J. D. (1998) Maintenance of diversity within plant communities: soil pathogens as agents of negative feedback. Ecology 79: 1595-1601.

Nechwatal, J. \& Oßwald, W. (2001) Comparative studies on the fine root status of healthy and declining spruce and beech trees in the Bavarian Alps and occurrence of Phytophthora and Pythium species. Forest Pathology 31 : 257-273.

Ostendorp, W. (1989) 'Die-back' of reeds in Europe - a critical review of literature. Aquatic Botany 35: 5-26.
Ostendorp, W., Dienst, M. \& Schmieder, K. (2003) Disturbance and rehabilitation of lakeside Phragmites reeds following an extreme flood in Lake Constance (Germany). Hydrobiologia 506-509: 687-695.

Packer, A. \& Clay, K. (2000) Soil pathogens and spatial patterns of seedling mortality in a temperate tree. Nature 404: 278-281.

Page, R. D. M. (1996) TREEVIEW: an application to display phylogenetic trees on personal computers. Computer Applications in the Biosciences 12: 357-358.

Rands, R. D. \& Dopp, E. (1934) Variability in Pythium arrhenomanes in relation to root rot of sugarcane and corn. Journal of Agricultural Research 49: 189-221.

Rea, N. (1996) Water levels and Phragmites: decline from lack of regeneration or dieback from shoot death. Folia Geobotanica \& Phytotaxonomica 31: 85-90.

Tsao, P. H. (1983) Factors affecting isolation and quantifcation of Phytophthora from soil. In Phytophthora: its biology, taxonomy, ecology, and pathology (D. C. Erwin, S. Bartnicki-Garcia \& P. H. Tsao, eds): 219-236. American Phytopathological Society Press, St Paul, MN

van der Plaats-Niterink, A. J. (1981) Monograph of the genus Pythium. Studies in Mycology 21: 1-242.

Waterhouse, G. M. (1968) The genus Pythium Pringsheim. Mycological Papers 110: 1-71.

White, T. J., Bruns, T., Lee, S. \& Taylor, J. (1990) Amplification and direct sequencing of fungal ribosomal RNA genes for phylogenetics. In PCR Protocols: a guide to methods and applications (M. A. Innis, D. H. Gelfand, J. J. Sninsky \& T. J. White, eds): 315-322. Academic Press, San Diego.

Wirsel, S. G. R., Leibinger, W., Ernst, M. \& Mendgen, K. (2001) Genetic diversity of fungi closely associated with common reed. New Phytologist 149: 589-598.

Wong, M. K. M. \& Hyde, K. D. (2001) Diversity of fungi on six species of Gramineae and one species of Cyperaceae in Hong Kong. Mycological Research 105: 1485-1491.

Corresponding Editor: D. E. L. Cooke 